\title{
ANALISIS PENGARUH RISIKO KREDIT TERHADAP IMBAL HASIL SAHAM PERBANKAN \\ DI BURSA EFEK JAKARTA \\ PERIODE TAHUN 2001-2005
}

\author{
Siane Handayani Rahardjo ${ }^{1}$ \\ BINUS Business School \\ Ingrid Maya Sophy ${ }^{2}$ \\ BINUS Business School \\ Tedy Fardiansyah ${ }^{3}$ \\ BINUS Business School
}

\begin{abstract}
Banks have an important role in the economy and serves as a financial intermediary. Credit risk, as one of indicator of the health of the bank, is an interest of all stakeholders including investors stock. This study was conducted to determine the effect of credit risk on bank stock returns listed on the Jakarta Stock Exchange. The sampling method performed on 8 banks for a sample of meeting the requirements of the study. Credit risk data consisting of CAR (Capital Adequacy Ratio), NPL (Non Performing Loans) and PPAP (Removal of Assets Allowance) financial ratios derived from the quarterly during January 2001-December 2005. The stock prices are taken from the weekly closing stock price data weekly during January 2001-December 2005.

Tests using multiple regressions were conducted to determine the effect of credit risk on stock returns. The results show that jointly or individually no significant effect on credit risk with stock returns.
\end{abstract}

Keywords : stock returns, credit risk, CAR, NPL, PPAP.

\footnotetext{
${ }^{1,2}$ Alumni of BINUS Business School

3 Faculty of BINUS Business School (affitedy@cbn.net.id)
}

78) Rahardjo, Siane H., et al / Journal of Applied Finance and Accounting 4(1) 78-94 


\begin{abstract}
ABSTRAK
Bank memiliki peran penting dalam perekonomian dan berfungsi sebagai lembaga intermediasi keuangan. Risiko kredit, sebagai salah satu indikator kesehatan bank, merupakan kepentingan semua pihak terkait termasuk investor saham.

Penelitian ini dilakukan dengan tujuan untuk mengetahui pengaruh risiko kredit terhadap imbal hasil saham bank yang terdaftar di Bursa Efek Jakarta.

Metode pengambilan sampel dilakukan terhadap 8 bank yang menjadi sampel penelitian karena memenuhi syarat-syarat penelitian. Data risiko kredit yang terdiri dari CAR (Capital Adequacy Ratio), NPL (Non Performing Loan), dan PPAP (Penghapusan Penyisihan Aktiva Produktif) berasal dari rasio keuangan kuartalan selama Januari 2001Desember 2005. Sedangkan harga saham mingguan diambil dari data harga saham penutupan mingguan selama Januari 2001-Desember 2005.

Pengujian dengan menggunakan regresi berganda dilakukan untuk mengetahui pengaruh risiko kredit terhadap imbal hasil saham. Hasil penelitian menunjukkan bahwa secara bersama-sama maupun individu tidak ada pengaruh yang signifikan terhadap risiko kredit dengan imbal hasil saham.
\end{abstract}

Kata kunci : imbal hasil saham, risiko kredit, CAR, NPL, PPAP.

\title{
PENDAHULUAN
}

Pembentukan Bursa Efek Jakarta (BEJ) sebagai wadah untuk transaksi pasar sekunder merupakan usaha pemerintah yang lebih nyata untuk mendorong perkembangan pasar modal di Indonesia. Kondisi ini disambut baik oleh perusahaan-perusahaan khususnya perbankan yang mempunyai peluang untuk melakukan go public. Perkembangan pasar modal dapat menarik investor dalam dan luar negeri untuk menanamkan dana yang dimilikinya dalam bentuk saham dari bank yang diminatinya.

Kegagalan restrukturisasi perbankan dapat menjadi krisis kepercayaan masyarakat maupun investor asing terhadap kinerja pemerintah, maka 
sangat berat buat dunia perbankan nasional untuk menarik minat para investor baru dan pemegang sahamnya sendiri untuk menambah setoran modal mencapai CAR minimalnya, yaitu 4\% (berdasarkan SE BI No 31/22/UPPB/1999 tanggal 11 Maret 1999 dan pada tanggal 31 Desember 2001 berdasarkan Peraturan Bank Indonesia Nomor 3/25/PBI/2001, minimum CAR diubah menjadi $8 \%$ yang sebelumnya $4 \%$.

Sementara pembenahan atas manajemen perbankan yang telah dilakukan oleh Bank Sentral melalui program "fit and proper test" yang diterapkan pada seluruh manajemen puncak perbankan. Penerapan atas "fit and proper test" dilakukan melalui penelusuran kembali terhadap semua kinerja perbankan, termasuk penelusuran kembali atas kemungkinan terdapatnya pelanggaran - pelanggaran yang telah dilakukan oleh baik pengurus dan profesional puncak maupun oleh pemegang saham masing - masing bank.

Sejalan dengan bergulirnya waktu, kondisi dunia perbankan nasional pasca pelaksanaan Program Rekap semakin lama semakin membaik di mana banyak bank peserta Program Rekap mampu memenuhi CAR minimalnya $8 \%$ dan menurunkan besaran NPLnya hingga di bawah $5 \%$.

Guna memenuhi kecukupan dana dalam sisi hutang dan kepemilikan modal sendiri guna membiayai aktiva serta untuk memenuhi CAR minimal yang ditetapkan oleh pemerintah, maka banyak bank yang melakukan go public dengan cara menerbitkan surat saham di pasar modal untuk ditawarkan kepada publik. Dengan kata lain mengapa bank-bank melakukan penerbitan surat saham adalah guna meningkatkan kemampuan likuiditas dan solvabilitas dalam pencapaian tingkat profitabilitas yang diharapkan serta meningkatkan ekuitasnya dalam sisi pasivanya.

Didasari oleh hal tersebut, maka penulis meneliti sejauh mana pengaruh risiko kredit dari bank yang telah listing di BEJ terhadap imbal hasil sahamnya di bursa efek. Oleh karenanya, penulis memilih judul "Analisa Pengaruh Risiko Kredit Terhadap Imbal Hasil Saham Perbankan di Bursa Efek Jakarta Periode Tahun 2001 - 2005”. 


\section{Rumusan Permasalahan}

Berdasarkan uraian latar belakang di atas, maka yang menjadi permasalahan dalam penulisan tesis ini, adalah :

Apakah pengaruh dari risiko kredit yang diwakili oleh variabel CAR, NPL, PPAP secara bersama-sama atau individual terhadap imbal hasil saham perbankan di Bursa Efek Jakarta periode tahun 2001-2005 ?

\section{LANDASAN TEORI}

\section{Kredit}

Menurut UU Perbankan nomor 10 tahun 1998, kredit adalah penyediaan uang atau tagihan yang dapat dipersamakan dengan itu, berdasarkan persetujuan atau kesepakatan pinjam meminjam antar bank dengan pihak lain yang mewajibkan pihak peminjam melunasi utangnya setelah jangka waktu tertentu dengan pemberian bunga.

Pembiayaan adalah penyediaan uang atau tagihan yang dapat dipersamakan dengan itu, berdasarkan persetujuan atau kesepakatan antara bank dengan pihak lain yang mewajibkan pihak yang dibiayai untuk mengembalikan uang atau tagihan tersebut setelah jangka waktu tertentu dengan imbalan atau bagi hasil.

\section{Risiko dalam Perbankan}

Berdasarkan Peraturan Bank Indonesia ada beberapa indikator utama dalam menilai kredit perbankan yaitu:

a. Rasio permodalan, yaitu Capital Adequacy Ratio (CAR)

Nilai CAR menunjukkan sejauh mana modal pemilik dapat menutupi aktiva berisiko. Rasio ini penting bagi pihak intern maupun ekstern perusahaan perbankan untuk menilai kemampuan perusahaan dalam mempertahankan kecukupan modal. Ketentuan besarnya CAR ditentukan minimum sebesar $8 \%$ berdasarkan Peraturan Bank Indonesia (PBI) nomor 3/21/PBI/2001 yang menggambarkan bahwa setiap 8 rupiah modal sendiri dapat menutupi 100 aktiva berisiko. Rasio CAR dihitung dengan formula berikut : 


$$
\mathrm{CAR}=\frac{\bmod \text { al sendiri }}{\text { aktiva tertimbang menurut risiko }} \times 100 \%
$$

b. Rasio Aktiva Produktif, yaitu Non Performing Loan ( NPL ) Rasio ini menggambarkan besarnya kredit bermasalah yang terjadi dalam satu periode. Semakin kecil nilai NPL berarti semakin kecil pula kredit yang bermasalah. Nilai NPL maksimal sebesar 5\% berdasarkan PBI nomor 3/25/PBI/2001 di mana setiap 100 rupiah total kredit yang diberikan terdapat maksimum 5 rupiah kredit yang bermasalah.

Rasio NPL dihitung dengan formula berikut :

$$
\mathrm{NPL}=\frac{\text { Kredit bermasalah }}{\text { Total kredit yang diberikan }} \times 100 \%
$$

c. Penyisihan Penghapusan Aktiva Produktif (PPAP)

1. PPAP adalah Penyisihan yang wajib dibentuk oleh bank untuk menutup risiko kerugian.

2. Besarnya pembentukan PPAP sekurang-kurangnya adalah :

a. $\quad 0,5 \%$ (setengah perseratus) dari aktiva produktif yang digolongkan lancar.

b. $10 \%$ (sepuluh perseratus) dari aktiva produktif yang digolongkan kurang lancar setelah dikurangi dengan nilai agunan yang dikuasai.

c. $\quad 50 \%$ (lima puluh perseratus) dari aktiva produktif yang digolongkan diragukan setelah dikurangi dengan nilai agunan yang dikuasai.

d. $100 \%$ (seratus perseratus) dari aktiva produktif yang digolongkan macet yang masih tercatat dalam pembukuan BPR setelah dikurangi dengan nilai agunan yang dikuasai.

Rasio PPAP dihitung dengan rumus:

$$
\frac{\text { PPAP yang telah dibentuk }}{\text { PPAP yang wajib dibentuk }} \times 100 \%
$$

82) Rahardjo, Siane H., et al / Journal of Applied Finance and Accounting 4(1) 78-94 


\section{Pengukuran Rasio dan Imbal Hasil Saham}

Dalam aktifitas investasi, baik investasi pada financial assets seperti saham maupun obligasi, maupun real assets seperti tanah dan bangunan pada umumnya mengandung dua hal yang perlu dipertimbangkan, yaitu risiko (risk) dan tingkat imbal hasil (return saham).

Bilamana suatu investasi memiliki risiko, berarti bahwa investasi tersebut tdidak dapat memberikan keuntungan yang pasti. Dalam keadaan ini, pemodal (investor) hanya akan mengharapkan untuk dapat memperoleh suatu tingkat imbal hasil tertentu. Imbal hasil (return) merupakan sejumlah hasil yang dapat diperoleh dari suatu aktifitas investasi yang dilakukan. Imbal hasil dapat berupa imbal hasil realisasi (realized return) yand merupakan imbal hasil yang telah terjadi, dihitung berdasarkan data historis, sebagai salah satu faktor penting yang digunakan dalam pengukuran kinerja dari suatu bank, dan digunakan sebagai dasar penentuan tingkat keuntungan yang diharapkan (expected return), serta risiko yang akan dihadapi pada masa datang. Rumusan yang digunakan dalam memperoleh tingkat imbal hasil realisasi ini, adalah:

$$
r i=\frac{p_{i}-p_{i-1}}{p_{i}}
$$

dimana :

$\mathrm{r}_{\mathrm{i}}=$ tingkat imbal hasil (return) realisasi pada saham $\mathrm{i}$

$\mathrm{p}_{\mathrm{i}} \quad=$ harga penutupan (closing price) pada hari ke $\mathrm{i}$

$\mathrm{p}_{\mathrm{i}-1}=$ harga penutupan (closing price) pada hari i-1

$\mathrm{n} \quad=$ jumlah observasi

\section{METODOLOGI PENELITIAN}

\section{Variabel}

Variabel-variabel yang akan diukur dalam penelitian ini dikelompokkan menjadi dua, yaitu:

a. Variabel terikat (dependent variable), dimana dalam penelitian ini adalah imbal hasil saham

b. Variabel bebas (independent variable), yang dalam penelitian ini adalah:

- Capital Adequacy Ratio (CAR) 
- Non Performing Loan (NPL)

- Penyisihan Penghapusan Aktiva Produktif (PPAP)

\section{Hipotesis}

Hipotesis untuk menguji apakah terdapat pengaruh yang signifikan dari keseluruhan variabel independent terhadap variabel dependent (menggunakan uji regresi berganda antara variabel independent terhadap variabel dependent).

$\mathrm{H}_{\mathrm{o}}$ : Tidak ada pengaruh yang signifikan dari risiko kredit yang terdiri dari CAR, NPL, PPAP secara bersama-sama ataupun individual terhadap imbal hasil saham perbankan .

$\mathrm{H}_{1}$ : Ada pengaruh yang signifikan dari risiko kredit yang terdiri dari $C A R, N P L, P P A P$ secara bersama-sama ataupun individual terhadap imbal hasil saham perbankan.

\section{Populasi dan Sampel}

1. Populasi. Bank yang listing di BEJ sejak tahun 2001-2005

2. Sampel. Dari populasi tersebut, dipilih sampel dengan teknik purposive sampling.

Berikut ini merupakan daftar perbankan yang sesuai dengan kriteria penelitian, yaitu :

1. Bank Central Asia

2. Bank Niaga

3. Bank Mayapada

4. Bank Artha Niaga Kencana

5. Lippobank

6. Bank Panin

7. Bank Mega

8. Bank Buana Indonesia

\section{Metode Analisis}

Ada beberapa metode untuk menganalisa data :

o Perhitungan imbal hasil saham

o Regresi Berganda

o Pengujian Hipotesis ada 3 cara

$$
\begin{aligned}
& R \text {-square } \\
& \text { F-test }
\end{aligned}
$$

84) Rahardjo, Siane H., et al / Journal of Applied Finance and Accounting 4(1) 78-94 


$\begin{array}{ll} & \text { T-test } \\ \text { o } & \text { Multicollinearity } \\ \text { o } & \text { Autocorrelation } \\ \text { o } & \text { Heteroscedasitcity } \\ \text { o } & \text { Uji Normalitas }\end{array}$

\section{Regresi Linier Berganda}

Analisis regresi berganda digunakan untuk memprediksikan bagaimana keadaan (naik turunnya) variabel dependen, bila dua atau lebih variabel independen sebagai faktor prediktor dimanipulasi (dinaik-turunkan nilainya). Jadi, analisis regresi ganda akan dilakukan bila jumlah variabel independennya minimal dua.

Untuk bisa membuat ramalan melalui regresi, maka data setiap variabel harus tersedia. Selanjutnya, berdasarkan data itu peneliti harus dapat menemukan persamaan melalui perhitungan. (Sugiyono, 2003, p210-211).

Model analisis dalam penelitian ini adalah sebagai berikut:

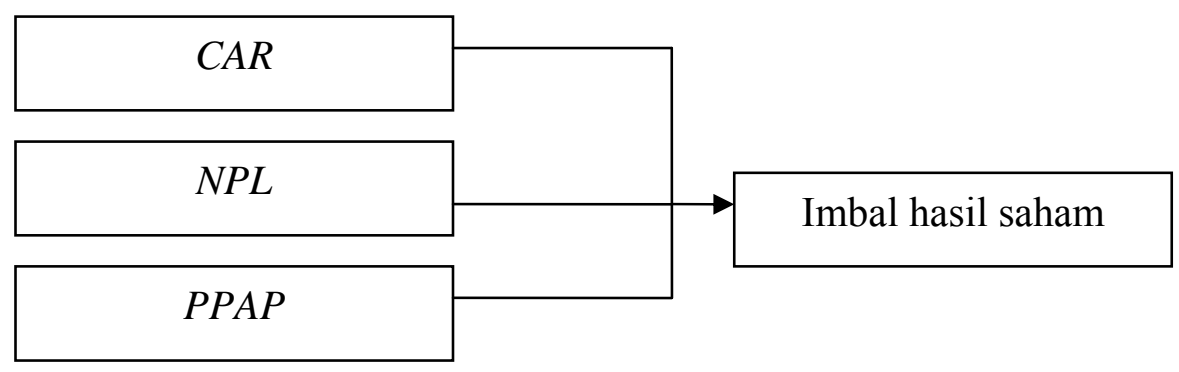

Persamaan untuk regresi berganda adalah :

$\mathbf{Y}=\mathbf{b}_{0}+\left(\mathbf{b}_{1} \times \mathbf{X}_{1}\right)+\left(\mathbf{b}_{2} \times X_{2}\right)+\left(\mathbf{b}_{3} \times X_{3}\right)+\ldots \ldots \ldots \ldots+\quad\left(b_{n} \times X_{n}\right)$

Sehingga dapat dibuat persamaan regresi berganda untuk perhitungan imbal hasil :

$$
Y_{1}=b_{0}+\left(b_{1} \times X_{1}\right)+\left(b_{2} \times X_{2}\right)+\left(b_{3} \times X_{3}\right)
$$


Keterangan :

$Y_{1}=$ Imbal hasil tiap sahamnya

$\mathrm{X}_{1}=\mathrm{CAR}$

$\mathrm{X}_{2}=N P L$

$\mathrm{X}_{3}=P P A P$

$\mathrm{b}_{0}=$ Konstanta

$\mathrm{b}_{1}=$ Konstanta untuk perhitungan $C A R$

$\mathrm{b}_{2}=$ Konstanta untuk perhitungan $N P L$

$\mathrm{b}_{3}=$ Konstanta untuk perhitungan $P P A P$

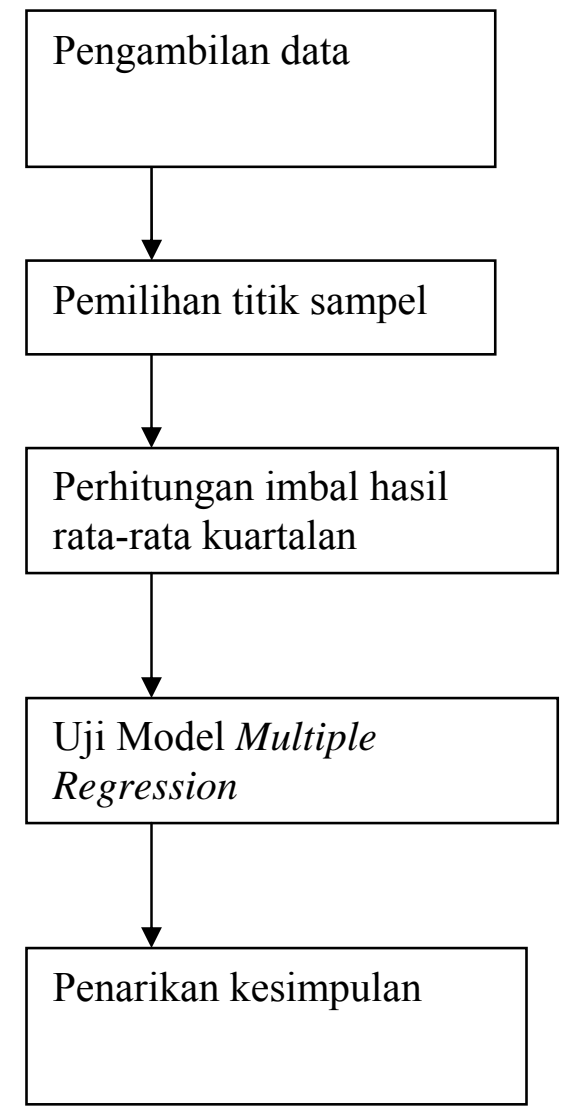

-Harga saham mingguan -Rasio keuangan

-Penentuan periode

-Penentuan jumlah sampel

Perhitungan imbal hasil mingguan rata-rata kuartalan

Rasio keuangan terhadap Imbal Hasil

Gambar 1. Diagram Alur Metode Penelitian

86) Rahardjo, Siane H., et al / Journal of Applied Finance and Accounting 4(1) 78-94 


\section{ANALISIS DAN PEMBAHASAN}

\section{Uji $R^{2}$ atau $R$ Square}

Dalam uji ini diperoleh koefisien korelasi ganda (R) yang menyatakan ukuran dari derajat keeratan hubungan antar variabel terikat dengan seluruh variabel bebas dan determinasi $\left(\mathrm{R}^{2}\right.$ atau $R$ Square $)$ yang menyatakan besarnya seluruh variabel bebas / independent dengan variabel terikat. / dependent. Berikut ini hasil uji $R$ Square :

Tabel 1. Uji R / R Square

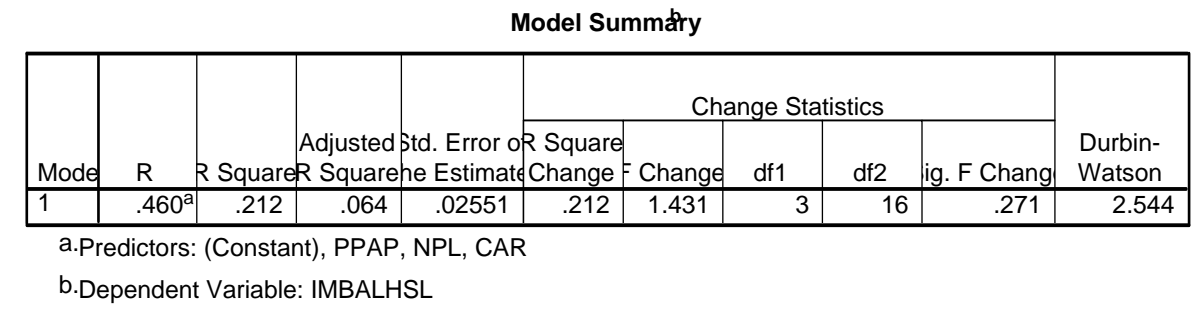

Dari tabel di atas dapat dilihat bahwa angka $R$ Square adalah 0.212 (adalah pengkuadratan dari koefisien korelasi, $\mathrm{R}$, atau $0.46 \times 0.46=$ $0.212)$. $R$ Square dapat disebut koefisien determinasi yang dalam hal ini berarti $21.2 \%$ imbal hasil saham dapat dijelaskan oleh variabel bebas (CAR, NPL , PPAP Ratio). Sedangkan sisanya (100\% - 21.2\% = $78.8 \%$ ) dijelaskan oleh sebab-sebab lain. $R$ Square berkisar pada angka 0 sampai 1 dengan catatan semakin kecil angka $R$ Square semakin lemah hubungan antar variabel terikat dengan variabel bebasnya.

\section{Uji F ( F-Test)}

Untuk mengukur pengaruh di antara $C A R, N P L, P P A P$ Ratio secara bersama-sama terhadap imbal hasil saham, maka terlebih dahulu akan dibahas mengenai uji regresi berganda dengan menggunakan F-test. Hasil Output uji regresi berganda tabel Anova dari SPSS adalah sebagai berikut: 
Tabel 2. ANOVA

ANOVA

\begin{tabular}{|ll|c|r|r|r|c|}
\hline \multicolumn{2}{|l|}{} & Sum of & & & & \\
\hline 1 & & Squares & $\mathrm{df}$ & Mean Square & $\mathrm{F}$ & \multicolumn{1}{c|}{ Sig. } \\
\hline & Regression & $2.795 \mathrm{E}-03$ & 3 & $9.316 \mathrm{E}-04$ & 1.431 & $.271^{\mathrm{a}}$ \\
& Residual & $1.041 \mathrm{E}-02$ & 16 & $6.508 \mathrm{E}-04$ & & \\
& Total & $1.321 \mathrm{E}-02$ & 19 & & & \\
\hline
\end{tabular}

a. Predictors: (Constant), PPAP, NPL, CAR

b. Dependent Variable: IMBALHSL

Dari tabel di atas, kita mendapat nilai koefisien F adalah sebesar 1.431 dengan tingkat signifikansi sebesar 0.271 atau $27.1 \%$.

Oleh karena nilai probabilitasnya di atas 5\%, maka diambil kesimpulan gagal menolak Ho, yang berarti tidak ada pengaruh yang signifikan dari $C A R, N P L, P P A P$ secara bersama-sama terhadap imbal hasil saham perbankan.

Tabel selanjutnya menggambarkan persamaan regresi:

$$
Y_{1}=-0.152+0.01053 X_{1}-0.00522 X_{2}-0.021 X_{3}
$$

Keterangan:

$$
\begin{aligned}
& \mathrm{Y}_{1}=\text { Imbal hasil tiap sahamnya } \\
& \mathrm{X}_{1}=C A R \\
& \mathrm{X}_{2}=\mathrm{NPL} \\
& \mathrm{X}_{3}=\text { PPAP }
\end{aligned}
$$

Tabel 3. Koefisien

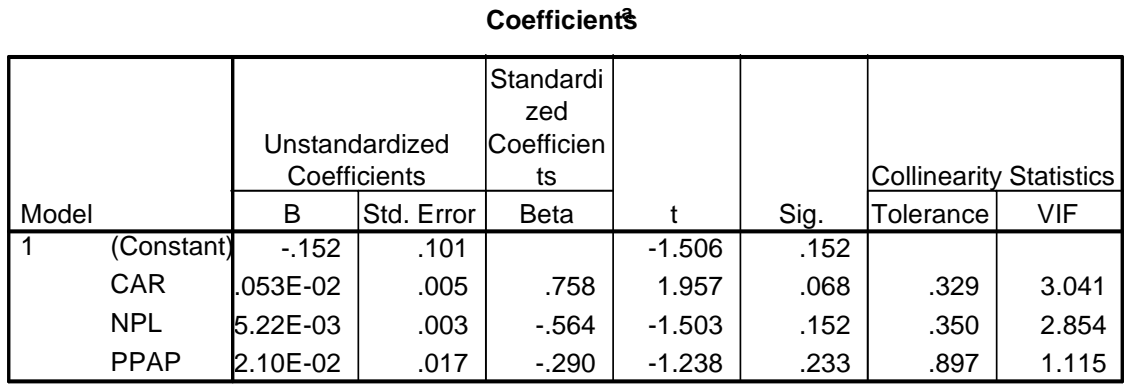

a. Dependent Variable: IMBALHSL

88) Rahardjo, Siane H., et al / Journal of Applied Finance and Accounting 4(1) 78-94 


\section{Uji t (t-Test)}

Uji $\mathrm{t}$ dilakukan untuk mengetahui apakah variabel-variabel independen secara individual / parsial memiliki pengaruh yang signifikan terhadap variabel dependen.

Dasar pengambilan keputusan:

Jika sig-t $>0.05$ berarti variabel independen tidak mempunyai pengaruh signifikan dengan variabel dependen.

Jika sig- $t<0.05$ berarti variabel independen mempunyai pengaruh signifikan dengan variabel dependen.

Tabel 4. Uji t (t-Test)

\begin{tabular}{|c|c|c|c|c|c|c|c|c|}
\hline \multicolumn{9}{|c|}{ Coefficients ${ }^{a}$} \\
\hline \multirow{2}{*}{\multicolumn{2}{|c|}{ Model }} & \multicolumn{2}{|c|}{$\begin{array}{c}\text { Unstandardized } \\
\text { Coefficients }\end{array}$} & $\begin{array}{l}\text { Standardi } \\
\text { zed } \\
\text { Coefficien } \\
\text { ts }\end{array}$ & \multirow[b]{2}{*}{$t$} & \multirow[b]{2}{*}{ Sig. } & \multicolumn{2}{|c|}{ Collinearity Statistics } \\
\hline & & $\mathrm{B}$ & Std. Error & Beta & & & Tolerance & VIF \\
\hline & (Constant) & -.152 & .101 & & -1.506 & .152 & & \\
\hline & CAR & 1.053E-02 & .005 & .758 & 1.957 & .068 & .329 & 3.041 \\
\hline & NPL & $-5.22 E-03$ & .003 & -.564 & -1.503 & .152 & .350 & 2.854 \\
\hline & PPAP & $-2.10 E-02$ & .017 & -.290 & -1.238 & .233 & .897 & 1.115 \\
\hline
\end{tabular}

a. Dependent Variable: IMBALHSL

Sig t untuk CAR $>0.05$ yang berarti tidak ada pengaruh yang signifikan dengan imbal hasil saham.

Sig t untuk NPL > 0.05 yang berarti tidak ada pengaruh yang signifikan dengan imbal hasil saham.

Sig $t$ untuk PPAP $>0.05$ yang berarti tidak ada pengaruh yang signifikan dengan imbal hasil saham.

\section{Uji Multikolinieritas}

Uji ini dilakukan untuk mengetahui apakah terjadi suatu kondisi multikolinieritas atau ill conditioning yang dapat membuat perhitungan yang diperlukan regresi menjadi tidak stabil, bahkan menjadi mustahil. Disebut collinear apabila dua atau lebih variabel bebas pada regresi berganda merupakan kombinasi linear antara masing-masing variabel. Indikator multikolinieritas dapat dilihat dari nilai Variance Inflation Factor (VIF) yang dapat dilihat dari tabel berikut. 
Pengujian multikolinieritas dirangkum pada tabel berikut:

Tabel 5. Pengujian Multikolineritas

\begin{tabular}{|l|l|l|l|l|}
\hline No. & $\begin{array}{l}\text { Variabel } \\
\text { Bebas }\end{array}$ & VIF & $\begin{array}{l}\text { Kriteria Terjadi } \\
\text { Multikolinieritas }\end{array}$ & Kesimpulan \\
\hline 1 & CAR & 3.041 & Nilai VIF $>10$ & Tidak Terjadi \\
\hline 2 & NPL & 2.854 & Nilai VIF $>10$ & Tidak Terjadi \\
\hline 3 & PPAP & 1.115 & Nilai VIF $>10$ & Tidak Terjadi \\
\hline
\end{tabular}

\section{Uji Autokorelasi}

Uji statistik Durbin-Watson akan membantu mendeteksi keberadaan autocorrelation dalam data. Ketika autocorrelation muncul di dalam data, maka validitas dari regresi menjadi sangat diragukan. Nilai dari uji Durbin-Watson melalui SPSS dapat dilihat pada tabel berikut:

Tabel 6. Hasil Uji Autokorelasi

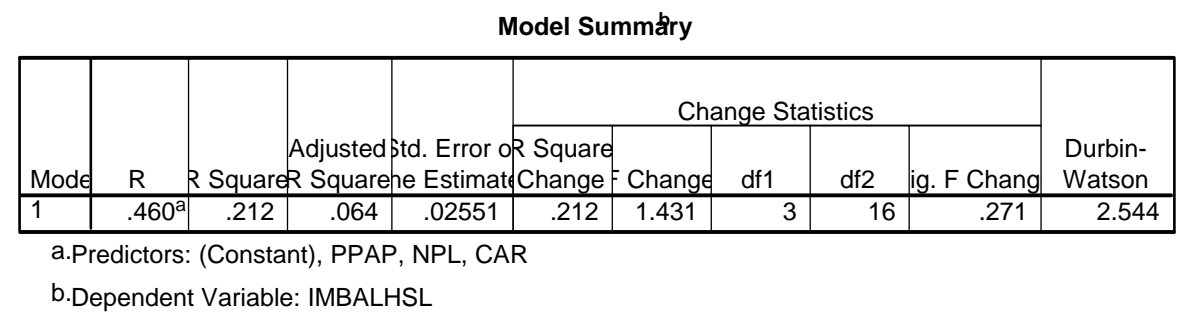

Dari tabel di atas, diperoleh nilai dari Durbin-Watson sebesar 2.544. dimana angka tersebut tidak berada di antara -2 dan +2 yang berarti terdapat autokorelasi negatif

\begin{tabular}{l|l|l}
\begin{tabular}{l|l} 
Autokorelasi \\
Positif
\end{tabular} & $\begin{array}{l}\text { Tidak Terdapat } \\
\text { Autokorelasi }\end{array}$ & $\begin{array}{l}\text { Autokorelasi } \\
\text { Negatif }\end{array}$ \\
\hline-2 & +2
\end{tabular}

90) Rahardjo, Siane H., et al / Journal of Applied Finance and Accounting 4(1) 78-94 


\section{Uji Heteroskedastisitas}

Uji asumsi heteroskedastisitas dimaksudkan untuk mengetahui apakah variasi residual absolut sama atau tidak sama untuk semua pengamatan. Apabila asumsi tidak terjadinya heteroskedastisitas tidak terpenuhi, maka penaksir menjadi tidak lagi efisien baik dalam sampel kecil maupun besar dan estimasi koefisien dapat dikatakan menjadi kurang akurat.

Tabel 7. Hasil Uji Heteroskedastisitas

\begin{tabular}{|c|c|c|c|c|c|c|c|c|}
\hline \multicolumn{9}{|c|}{ Coefficients $^{\mathrm{a}}$} \\
\hline \multirow{2}{*}{\multicolumn{2}{|c|}{ Model }} & \multicolumn{2}{|c|}{$\begin{array}{c}\text { Unstandardized } \\
\text { Coefficients }\end{array}$} & $\begin{array}{l}\text { Standardi } \\
\text { zed } \\
\text { Coefficien } \\
\text { ts }\end{array}$ & \multirow[b]{2}{*}{$\mathrm{t}$} & \multirow[b]{2}{*}{ Sig. } & \multicolumn{2}{|c|}{ Collinearity Statistics } \\
\hline & & $\mathrm{B}$ & Std. Error & Beta & & & Tolerance & VIF \\
\hline & (Constant) & -.152 & .101 & & -1.506 & .152 & & \\
\hline & CAR & 1.053E-02 & .005 & .758 & 1.957 & .068 & .329 & 3.041 \\
\hline & NPL & $-5.22 E-03$ & .003 & -.564 & -1.503 & .152 & .350 & 2.854 \\
\hline & PPAP & $-2.10 \mathrm{E}-02$ & .017 & -.290 & -1.238 & .233 & .897 & 1.115 \\
\hline
\end{tabular}

a. Dependent Variable: IMBALHSL

Dari tabel di atas dapat dilihat bahwa tingkat signifikansi masingmasing variabel bebas adalah lebih besar dari $\alpha=0.05$, oleh karena itu dapat diambil kesimpulan gagal menolak Ho, yang berarti tidak terjadi heteroskedastisitas dalam data.

\section{Uji Normalitas}

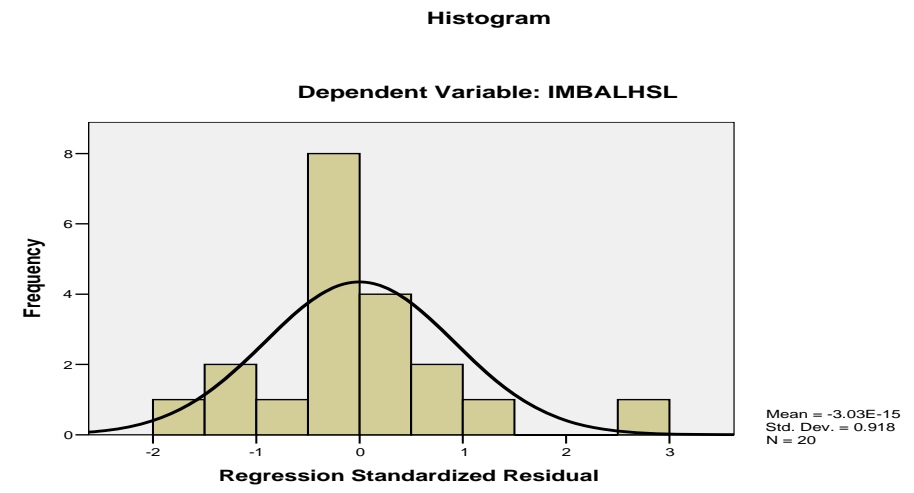

Gambar 2. Histogram Hasil Uji Normali 


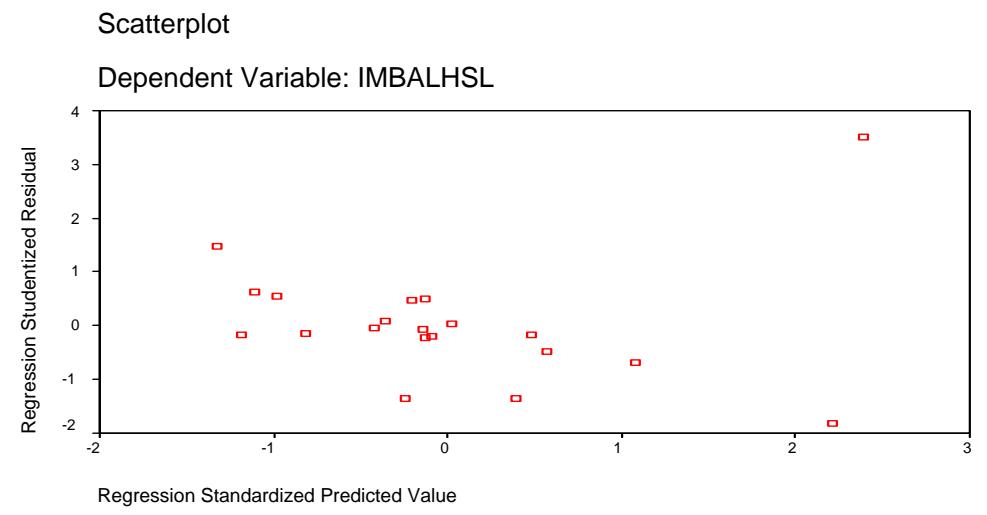

Gambar 3. Scatterplot Hasil Uji Normalitas

Dari grafik normal PP Plot tampak bahwa residual terdistribusi secara normal dan berbentuk simetris. Pada scatterplot, titik menyebar di sekitar garis, ini menunjukkan bahwa residual terdistribusi secara normal.

\section{KESIMPULAN DAN SARAN}

\section{Kesimpulan}

Berdasarkan pengolahan data yang telah dilakukan, dapat disimpulkan bahwa:

1. Menurut perhitungan perusahaan secara rata-rata, menyimpulkan bahwa:

Tidak ada pengaruh yang signifikan dari risiko kredit yang meliputi CAR, NPL, PPAP secara bersama-sama terhadap imbal hasil saham-saham perbankan selama periode 2001-2005.

2. Akan tetapi apabila perhitungan dilakukan terhadap setiap variabel independen secara individual terhadap imbal hasil saham dapat disimpulkan bahwa:

- Tidak ada pengaruh yang signifikan dari CAR terhadap imbal hasil saham perbankan.

- $\quad$ Tidak ada pengaruh yang signifikan dari NPL terhadap imbal hasil saham perbankan.

92) Rahardjo, Siane H., et al / Journal of Applied Finance and Accounting 4(1) 78-94 
- $\quad$ Tidak ada pengaruh yang signifikan dari PPAP terhadap imbal hasil saham perbankan.

\section{Saran}

Adapun saran-saran yang dapat dijadikan bahan masukan di antaranya adalah:

1. Perlu dilakukan penelitian lebih mendalam tentang seberapa besar pengaruh dari faktor-faktor fundamental dan faktor-faktor ekonomi terhadap keputusan investor dalam melakukan jual-beli saham perbankan di Bursa Efek Jakarta.

2. Perlu adanya penelitian lebih lanjut untuk mengetahui faktor yang paling dominan (sebagai dasar) dalam memilih saham perbankan sehingga investor dapat memperoleh bahan-bahan pertimbangan lebih lanjut.

3. Investor dapat menggunakan faktor variabel independen lain selain CAR, NPL, PPAP sehingga memperoleh bahan-bahan pertimbangan lain untuk menakar imbal hasil yang diharapkan pada saham-saham perbankan di Bursa Efek Jakarta.

4. Untuk penelitian selanjutnya, sebaiknya jumlah observasi lebih diperbanyak (dari periode waktu penelitian dan jumlah emiten yang diteliti). Dengan semakin banyaknya jumlah observasi maka diharapkan dapat memperoleh hasil pengujian yang lebih tepat dan akurat.

\section{DAFTAR PUSTAKA}

Ali, Masyud H., 2002, Restruksturisasi Perbankan dan Dunia Usaha, PT. Elex Media Komputindo, Jakarta.

Badudu, J. S. dan Zain, Sutan Mohammad. (2001). Kamus Umum Bahasa Indonesia. Pustaka Sinar Harapan, Jakarta.

Dahlan S., 1999, Manajemen Lembaga Keuangan, Edisi Dua, Lembaga Penerbit Fakultas Ekonomi Universitas Indonesia, Jakarta.

Harmawan, Widyo, 2005, Analisis Pengaruh Kinerja Bank Rekap Terhadap Imbal Hasil Saham di Bursa Efek Jakarta Periode 
Tahun 2000-2004, Thesis, Program Pascasarjana MM Manajemen Keuangan, Universitas Bina Nusantara, Jakarta.

Humanika, 2001, BLBI : Megaskandal Ekonomi Indonesia, Cetakan I, Hurnanika, Jakarta.

Irianto, Agus, 2004, Statistik Konsep Dasar \& Aplikasinya, Edisi Pertama, Prenada Media, Jakarta.

Kasmir, 2004, Manajemen Perbankan, PT. RajaGrafindo Persada, Jakarta.

Muljono, Teguh Pudjo, 1999, Analisa Laporan Keuangan untuk Perbankan, Edisi Enam, Djambatan, Jakarta.

Riyadi, Selamet, 2003, Banking Assets and Liabilites Management, Lembaga Penerbit Fakultas Ekonomi Universitas Indonesia, Jakarta.

Walpole, Ronald E., 1995, Pengantar Statistik, Edisi Tiga, PT. Gramedia, Jakarta

94) Rahardjo, Siane H., et al / Journal of Applied Finance and Accounting 4(1) 78-94 